板面内で進行するこの破壊過程の連続的な観察をおこなっ た結果, 次のような結論を得た。

この破壊は Fig.4に図式的に示した各段階を経て全体 の破断が完了する。

（1）破断開始点間近になると交叉した巨視的な剪断変形 集中帯が形成される．この剪断变形集中帯は大局的にこれ 之同方向に並んだ数多くのもっと幅の狭い剪断変形集中帯 で構成されている。

(2) 巨視的な剪断変形集中帯が交叉した萆形の領域でボ イドの形成・成長が促進される，交必した巨視的な剪断变 形集中帯内部のボイドを多く含んた剪断変形集中帯に変形 が集中しさらにボイドの形成・成長を促進するといら変形 の集中が加速度的に進行しボイドの著しく成長・凝集した 領域が複数個出現する。

(3)これらの領域で成長したボイドが連結して複数個の 小クラックが生じる。これが破断開始点である。

(4)これらの小クラックが連結して一つのセンタークラ ックをなる。

(5) センタークラックがクラックの進行に都合の良い拎 断変形集中帯にボイドシートを形成しながらジグザグに伝
播する。

(6) センタークラック先端の剪断変形集中带が試片端部 に到達し，その部分が急激に口を開いて全体的な破断が完 了する。

このように交攴する剪断変形集中帯の形成は破断開始点 に至る臨界の段階であると共に煎断変形集中带は破壞過程 においてる重要な役割を果している。

な和，銅丸棒の1軸引張変形による延性破壊過程との対 比検討の結果，得られた結論は丸棒に打ける延性破壞過程 に対してもあてはまると考劣られる。

終りに臨み，本報告を執筆するにあたり有益なご示唆ご 討論を頂いた東京大学宇宙航空研究所 堀内 良教授, 岸 輝雄助教授に深く感謝の意老します。

\section{文輔}

（1）丹羽直毅,大久保忠恒：日本金属学会誌，39(1975), 635.

（2）丹羽值毅,大久保忠恒：日本金属学会誌，40(1976), 399.

(3) H.C.Rogers : Trans. Met. Soc. AIME, 218 $(1960), 498$.

\title{
鉄鋼のイオン軟窒化における拡散層および 化合物層の生成速度について*
}

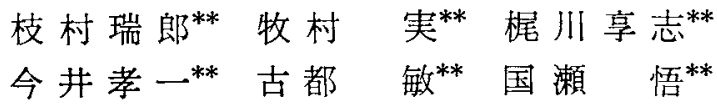

Mizuo Edamura, Minoru Makimura, Takashi Kajikawa, Kōichi Imai, Satoshi Furuitsu and Satoru Kunise: The Kinetic Aspects of Diffusion Zone and Compound Layer Formed by Ion-softnitriding. The depth of the diffusion zone and the thickness of the compound layer of the ion-softnitrided $\mathrm{S} 15 \mathrm{C}$ steel were investigated by optical microscopy by varying the nitriding temperature $\left(450 \sim 600^{\circ} \mathrm{C}\right)$ and time $(0.25 \sim 30 \mathrm{~h})$.

The main results were as follows.

(1) The growth rate of the diffusion zone followed the parabolic law. In the diffusion zone, the activation energy for diffusion of nitrogen was calculated to be $7.53 \times 10^{4} \mathrm{~J} / \mathrm{mol}$ $\left(1.80 \times 10^{4} \mathrm{cal} / \mathrm{mol}\right)$ by assuming the temperature dependency of the nitrogen concentration at the diffusion zone-compound layer interface.

(2) The concentration of the nitrogen at the top surface of the compound layer was concluded as $11.35 \mathrm{wt} \%$ which corresponded to that of the $\zeta-\mathrm{Fe}_{2} \mathrm{~N}$ phase.

(3) The growth rate of the compound layer followed the linear law during the first 30 min, after which it approximately followed the parabolic law. In the compound layer, the activation energy for diffusion of nitrogen was calculated as $8.46 \times 10^{4} \mathrm{~J} / \mathrm{mol}\left(2.02 \times 10^{4} \mathrm{cal} / \mathrm{mol}\right)$ by assuming the top surface nitrogen concentration to be $11.35 \mathrm{wt} \%$ which corresponded to the $\boldsymbol{\zeta}-\mathrm{Fe}_{2} \mathrm{~N}$ phase and the temperature dependency of the nitrogen concentration at the diffusion zone-compound layer interface.

(4) The diffusion coefficient of nitrogen in the compoud layer was very small compared to that in the diffusion zone.

(Received April 25, 1978)

**川崎重工業株式会社発動機事業本部(Engine and Motorcycle Group, Kawasaki Heavy Industries Ltd., Akashi)

* イオン軟窒化の研究 (第 3 報) 


\section{I. 緒言}

著者らはすで沉(2)イオン軟窒化における処理因子（ガ ス組成，全ガス圧，グロ一電流密度，グロ一電圧）が最表 面部の化合物買およびそれに続く拡散層から成る窒化層の 生成に及济す影響について，イオン空化の場合とも比較し ながら詳細に検討してきた，ところで一方，イオン欶窒化 の上記以外の重要な処理因子である窒化温度 ·時間と窒化 層の生成速度がどのような関係にあるかということる極め て興味深い問題である。しかしこの問題について定量的 に検討した研究は少ないょうである。そこで本研究では， まず抬散層の生成速度について，抬散層の化合物層との界 面窒素濃度の温度依存性を考虑して唡討し，払散層中のN の抎散係数を求めた。次に，化合物層の生成速度について は，従来必ずしも明確にされていなかった化合物層の最表 面窒素濃度を実験により決定するとともに，化合物層の払 散層との界面窒素濃度扰よび拡散層の化合物層との界面窒 素濃度の温度传存性，さらに先に求めた抎散屏中のNの抬 散保数も考慮して検討し，化合物層中のNの拡散係数を求 めた。ただし，化合物層に拁いては，窒化時間が短いあい だとそれ以降で生成速度に大きな差異が認められたので， この点についても検討した。

\section{II. 試料および実験方法}

実験に用いた試料は S 15C であり，Table 1 にとの化 学成分之前処理を示した。試料の形状は $\phi 15 \times H 50$ の円柱 状である，ただし，化合物層の最表面窒素濃度を決定する 実験では純 Ti 棒(JIS：TB 35 C) の試料子使用した.

Table 1 Chemical composition(wt\%) and heat treatment of specimen.

\begin{tabular}{|c|c|c|c|c|c|c|}
\hline peci & C & $\mathrm{Si}$ & $\mathrm{Mn}$ & $\mathrm{P}$ & S & Heat treatment \\
\hline $\mathrm{S}$ & & & & 0.010 & 0.018 & $930^{\circ} \mathrm{C}$ \\
\hline
\end{tabular}

処理装置は前報(1)と同じものを使用した，全ガス圧はマ クラウド真空計で測定した。温度測定にはインコネルで被 覆した $\mathrm{CA}$ 熱電対を用いた。

イオン軟窒化処理の1サイクルをFig.1に示した。昇 温拉よび窒化処理中に打いて，イオン衝撃時に発生する熱 による加熱以外に発熱体による加熱も併用した。この方法 を用いることにより，処理条件の如何にかかわらずグロー 電流密度を一定に保つことなどができ，試料の温度分布む 均一に保持することができる。なお，ガス比，全ガス压， グロー電流密度はそれぞれ $\mathrm{N}_{2}: \mathrm{H}_{2}=2: 1$ (添加 $\mathrm{C}_{3} \mathrm{H}_{8}: 1$ vol\%)，400 Pa (3 torr), $11.5 \mathrm{~A} / \mathrm{m}^{2}$ と一定にした. ただ し，化合物層の最表面窒素濃度を決定する実験について は,グロ一電流密度を $34.5 \mathrm{~A} / \mathrm{m}^{2}$ と高くした，窒化処理 後はただちに吙を開き，試料を別に設けた冷却槽にて水冷 した，水冷時の試料表面の冷却速度は $700^{\circ} \mathrm{C} / \mathrm{s}$ である。

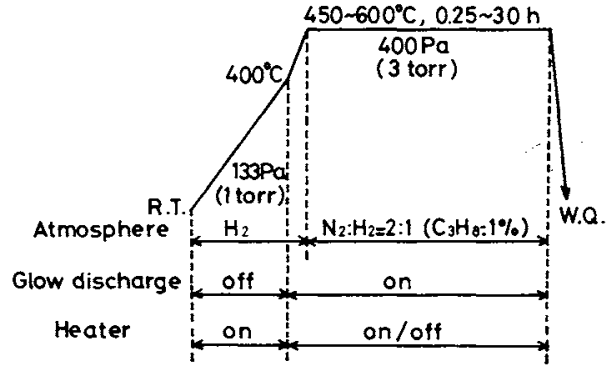

Fig.1 One cycle of ion-softnitriding.

\section{III．実験結果および考察}

\section{1. 拡散屋の生成速度}

窒化温度，窒化時間を変えてイオン軟窒化し，ただちに 水冷した後, $300^{\circ} \mathrm{C} て ゙ 1 \mathrm{~h}$ 時効して $\gamma^{\prime}-\mathrm{Fe}_{4} \mathrm{~N}$ 針状組䅧が 認められる深さを拡散層深さ $X_{1}$ と定義すれぱ，Fig.2に 示したように, 各窒化温度に打引る拡散層深さの 2 乗 $X_{\mathrm{I}}^{2}$ 々窒化時間 $t$ の間には㨁線関係が成立していた。このこと から，拡散風の生成速度は放物線則佳うことがわかっ た。

一方，Fig.3 は化合物層IIを形成しつつ窒素が払散する 場合に护る窒素の濃度分布の模式図である。い亲执散層

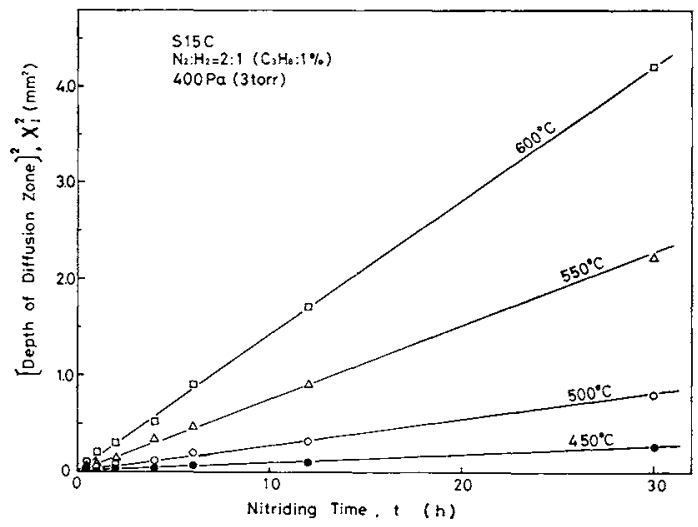

Fig.2 Relation between the square of the depth of the diffusion zone and nitriding time.

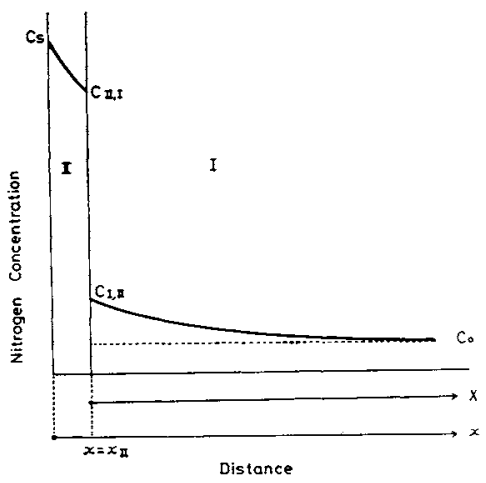

Fig.3 Schematic diagram of nitrogen concentration distribution. 
Iについて着目し拡散方程式を解くと，任意の深さ $X$, 空化時間 $t$ 亿打外る空素の濃度 $c$ は，拡散層中の窒素の拡 散係数を $D_{\mathrm{I}}$ とし, 試料の窒素の初濃度を零々す机ば次式 で与えられる。

$$
c=c_{\mathrm{I}, \mathbb{I}}\left\{1-\operatorname{erf}\left(k_{\mathrm{I}}\right)\right\}
$$

ただし，

$$
\begin{aligned}
& \operatorname{erf}\left(k_{\mathrm{I}}\right)=(2 / \sqrt{\pi}) \int_{0}^{k_{\mathrm{I}}} e^{-\eta^{2}} d \eta \\
& k_{\mathrm{I}}=X / 2 \sqrt{D_{\mathrm{I}} t}
\end{aligned}
$$

ここで， $c_{\mathrm{I}, \mathbf{r}}$ は搪散層の化合物層との界面窑素濃度て あり， $\alpha$ - Fe の飽和空素濃度として Fig.4の Fe-N 状態 図(3)から求めることができる(4)。なお， $X$ 座標の原点は $t$ とともに移動するが，その移動距離は搪散層深さに比べて 充分無視でさる。

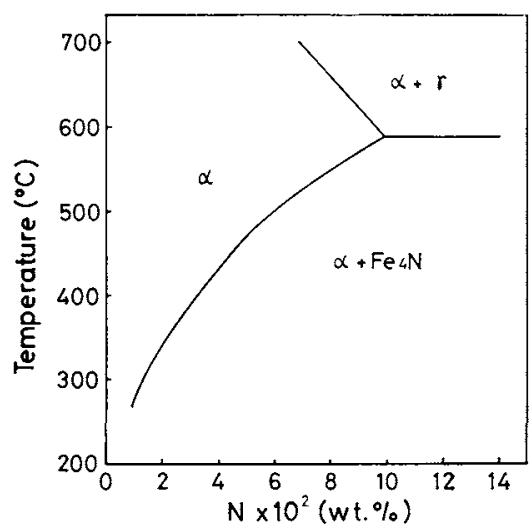

Fig.4 Iron-nitrogen phase diagram.

さて，前述したよらにイオン軟窒化し，ただちに水冷し た後, $300^{\circ} \mathrm{C}$ で $1 \mathrm{~h}$ 時効して $\gamma^{\prime}-\mathrm{Fe}_{4} \mathrm{~N}$ 針状組織が認めら れる深さを抬散㬝深さ $X_{1}$ と定義したので，Fig.4 から

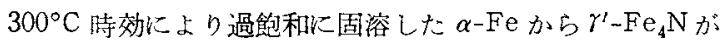
析出可能な限界窒素濃度を求めると $0.015 \mathrm{wt} \%$ であっ た。 そこで， $c=0.015 \mathrm{wt} \%$ となる $X$ を搪散層潹さ $X_{\mathrm{I}}$ と すれば，各窒化温度の $c_{\mathbf{I}, \mathbf{I}}$ に対し式(1)，(2)より $k_{\mathrm{I}}$ は 得られるので，その值を $k_{I_{c}}$ とすれば式(3)より

$$
X_{1}^{2}=\left(4 k_{1_{c}}^{2} D_{\mathrm{I}}\right) t
$$

となる。

したがって，Fig.2の各直線の傾きと式 (4)の $\left(4 k_{\mathrm{I}_{c}}^{2} D_{\mathrm{I}}\right)$

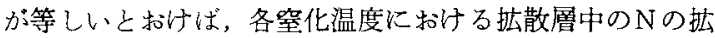
散係数 $D_{\mathrm{I}}$ は容易に求交り，Fig.5の上うに Arrhenius の式で整理すると，拡散層中のNの拡散の活性化エネルギ 一は $7.53 \times 10^{4} \mathrm{~J} / \mathrm{mol}\left(1.80 \times 10^{4} \mathrm{cal} / \mathrm{mol}\right)$ であった。これ は $\alpha$ - $\mathrm{Fe}$ 中の $\mathrm{N}$ の挔散の活性化エネルギー 7.53 7.79x $10^{4} \mathrm{~J} / \mathrm{mol}\left(1.80 \sim 1.86 \times 10^{4} \mathrm{cal} / \mathrm{mol}\right)^{(5)}$ とよく一致してお り，イオン軟至化の場合る报散層の生成速度は通常の $\alpha$ $\mathrm{Fe}$ 中のNの拡散支配に従うと考兄て上いことがわかった。 このことは従来のイホン窒化に関して得られた知見 ${ }^{(6)}$ とは 必ずしも一致しないが、これはそれらの研究では,上り簡便

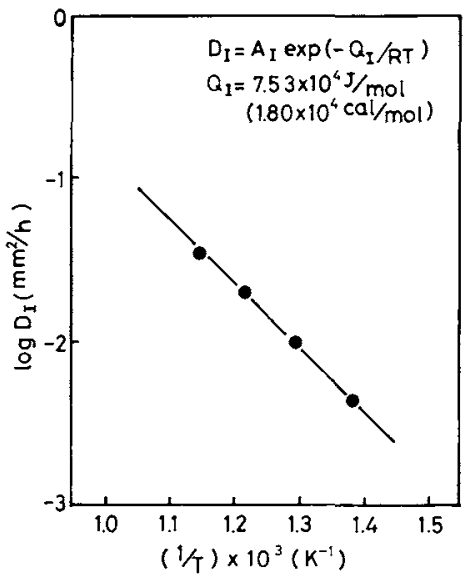

Fig.5 Relation between the diffusion coefficient of nitrogen in the diffusion zone and the reciprocal of absolute temperature.

な近似式を採用しているなめと考古られる，な拉，前報11 で窒化温度，窒化時間を一定 $\left(550^{\circ} \mathrm{C}, 6 \mathrm{~h}\right)$ にして，ガス組 成, 全ガス圧, グロー電流密度, グロー電生を变えてイオ ン窒化もしくはイオン軟窒化したところ，拡散層深さはほ ば一定であることを確認している。

\section{2. 化合物層の生成速度}

(1) 化合物層の生成モデル

Fig.6に $450 \sim 600^{\circ} \mathrm{C}$ でイオン軟窒化したときの化合物 層厚さ $x_{\mathbf{I}}$ と窒化時問 $t$ の関係を雨対数グラフで示した. ただし，窒化温度が $600^{\circ} \mathrm{C}$ の場合は $3 \%$ ナイタールの腐食 で化合物層に続いて 7 8 $\mu \mathrm{m}$ の白色層が認められた。こ で，化合物屬を除去してX線回折を行なうとオーステナイ トが同定されたので，この層の厚さは化合物層厚さに含め ていない。ちなみにイオン軟空化後の泠却方法は水冷であ り， $\mathrm{Fe}-\mathrm{N}$ の共析組成に拈けるオーステナイトの Ms 点 ${ }^{(7)}$ は $0^{\circ} \mathrm{C}$ 以下である。図から窒化時間が $0 \sim 0.5 \mathrm{~h}$ では化合 物層厚さ $x_{\mathbf{I}}$ と窒化時間 $t$ の間に 1 次則が成立し, $0.5 \mathrm{~h}$ 以 上では注涪放物線則が成立することがわかった。これは試 料表面に窒化鉄が一旦生成されれば，化合物層II生成は 表面反安支配から抁散支配に移行することを示している。

いま，化合物層厚さ $x_{\mathbf{I}}$ は化合物層中の窒素の拡散係数 を $D_{\mathbf{I}}$ としたとき

$$
x_{\mathbf{I}}=2 k_{\mathbf{I}} \sqrt{\overline{D_{\mathbf{I}} t}}
$$

といら放物線則に従うと仮定し，Fig.3の上らに試料表面 からの距離を $x$ として昖散方程式

$$
\begin{array}{ll}
\frac{\partial c}{\partial t}=D_{\mathbb{I}} \frac{\partial^{2} c}{\partial x^{2}} & \left(0<x<x_{\mathbf{I}}\right) \\
\frac{\partial c}{\partial t}=D_{\mathbf{I}} \frac{\partial^{2} c}{\partial x^{2}} & \left(x>x_{\mathbf{I}}\right)
\end{array}
$$

を次の初期ないし境界条件

$$
\begin{aligned}
& c=c_{0} \quad(x>0, t=0) \\
& c=c_{s} \quad(x=0, t>0) \\
& c=c_{\mathbf{I}, \mathrm{I}} \quad\left(x=x_{\mathbf{I}}-0\right)
\end{aligned}
$$




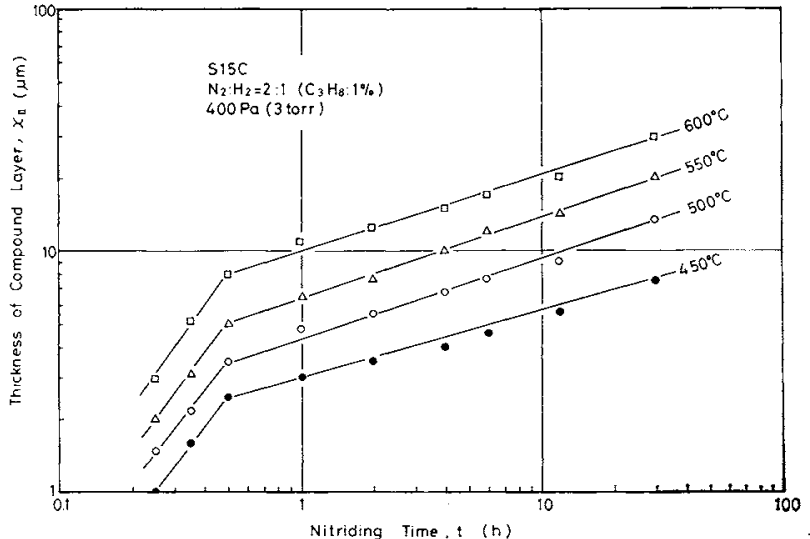

Fig.6 Effect of nitriding time upon the thickness of the compound layer.

$$
c=c_{\mathrm{I}, \mathbf{I}} \quad\left(x=x_{\mathbf{I}}+0\right)
$$

および

$$
\begin{aligned}
& {\left[c_{\mathbf{I}, \mathrm{I}}-c_{\mathbf{I}, \mathbf{I}}\right] \mathrm{d} x_{\mathbf{I}}} \\
& =-D_{\mathbb{I}}\left(\frac{\partial c}{\partial x}\right)_{x_{\mathbb{I}} \rightarrow 0}+D_{\mathrm{I}}\left(\frac{\partial c}{\partial x}\right)_{x_{\mathbb{I}}+0}
\end{aligned}
$$

のもとで解くと

$$
=\frac{\left(c_{s}-c_{\mathbf{I}, \mathbf{I}}\right) \exp \left(-k_{\mathbf{I}}^{2}\right)}{\sqrt{\pi} k_{\mathbf{I}} \operatorname{erf}\left(k_{\mathbf{I}}\right)}-\frac{\left(c_{\mathrm{I}, \mathbf{I}}-c_{0}\right) \exp \left(-k_{\mathbf{I}}^{2}\right)}{\sqrt{\pi \varphi} k_{\mathbf{I}}\left\{1-\operatorname{erf}\left(k_{\mathbf{I}} \sqrt{\varphi}\right)\right\}}
$$

となる(8).

ここで， $\varphi$ は化合物層と払散層の拡散係数の比 $D_{\mathbf{I}} / D_{\mathrm{I}}$ であり，上式から $\varphi$ を求めれば前述 (Fig.5)の $D_{\mathrm{I}}$ から $D_{\mathbf{I}}$ を知ることができる。

\section{（2）境界窒素縟度の決定}

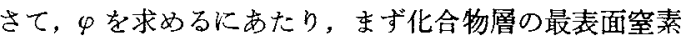
濃度 $c_{s}$ を次のよ5にして求めた，陰極支持台に S $15 \mathrm{C}$ と 純 Ti(JIS：TB 35 C) の試料を Fig.7に示したよ5にセッ トし，比較的高いグロー電流密度 $\left(34.5 \mathrm{~A} / \mathrm{m}^{2}\right)$ でイオン軟 窒化し，水冷した後，純 $\mathrm{Ti} の$ 試料側面をX線回折した。

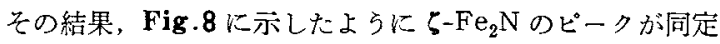
された(Tiの窒化物は同定されなかった)。これは S $15 \mathrm{C}$ 試料へのグロー放電によるスパッタリング作用のため, ス パッタされた Feないし窒化鉄が紝 $\mathrm{Ti}$ 試料にら-Fe $\mathrm{e}_{2} \mathrm{~N}$ と

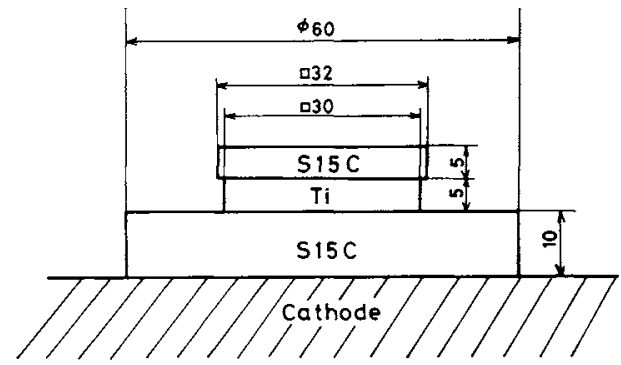

Fig.7 Setting position of pure titanium and S $15 \mathrm{C}$ steel.

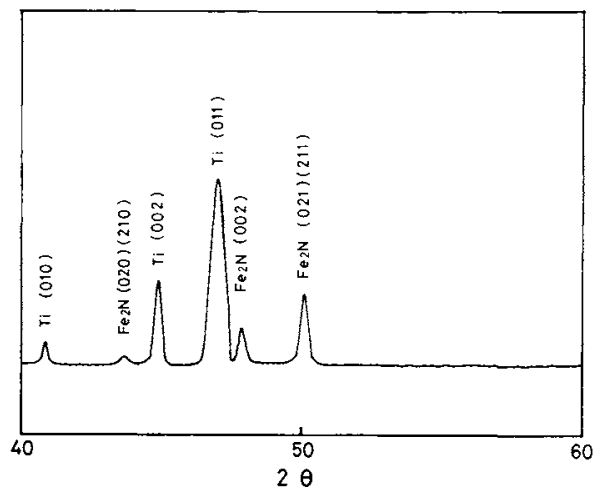

Fig.8 X-ray diffraction pattern obtained from the surface of pure titanium which was ion-softnitrided near S15C steel.

して付着したことによると考穴られる。したがって，csに は $\zeta-\mathrm{Fe}_{2} \mathrm{~N}$ に相当する窒素濃度 $11.35 \mathrm{wt} \%$ を仮起した。

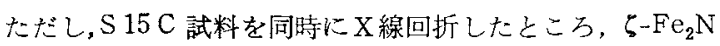

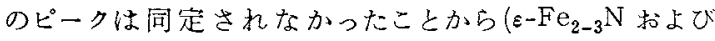

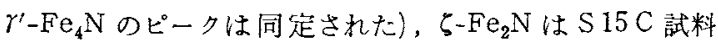
表面ではNを試料中に搪散しつつ，低濃度の窒化鉄である $\varepsilon-\mathrm{Fe}_{2-3} \mathrm{~N}$ p $\gamma^{\prime}-\mathrm{Fe}_{4} \mathrm{~N}$ になると考光られる。李た $\mathrm{S} 15 \mathrm{C}$ 試 料から、下i ないしその化合物は同定されなかった。これは $\mathrm{Ti}$ が Feに比べてスパッタリングされにくい(9)ためと考 えられる。

一方，化合物層の拡散層との界面窒素濃度 $c_{\mathbf{I}, \mathbf{I}}$ につい ては次のよらにして求めた。前報(2)で述べたように S $15 \mathrm{C}$ の化合物層に生成さ机る空化鉄は，各窒化温度とも $\varepsilon-$ $\mathrm{Fe}_{2-3} \mathrm{~N} と \gamma^{\prime}-\mathrm{Fe}_{4} \mathrm{~N}$ の 2 相から成っている. したがって， $c_{I, I}$ は各窒化温度とも $\gamma^{\prime}-\mathrm{Fe}_{4} \mathrm{~N}$ の最大固溶空素濃度(10) 仮定した。 また拡散層の化合物層との界面窒素濃度 $c_{\mathrm{I}, \mathbf{I}} に$ ついては，前述の $D_{\mathrm{I}}$ を求めたとさに使用した値をそのま ま用いた。陚料の窒素の初濃度 $c_{0}$ も $D_{\mathbf{I}}$ を求めたとをと 同様に零とした。

(3) 化合物庴中の Nの拡散保数

さて, 式(5)拉よび $\varphi=D_{\mathbf{I}} / D_{\mathbf{X}}$ から

$$
x_{\mathbb{I}}^{2}=\left(4 k_{\mathbb{I}}^{2} \varphi D_{\mathrm{I}}\right) t
$$

となる。一方, Fig.9はFig.6を $x_{\mathbb{I}}^{2}$ と $t$ の関保にプロッ トしなおした図である。前述したように $t$ が $0.5 \mathrm{~h}$ 以上で

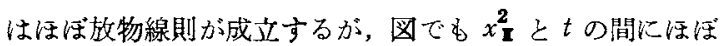
直線関保が成立している。そこで，图の各直線の傾きと 式(14)の $\left(4 k_{\Pi}^{2} \varphi D_{\mathrm{I}}\right)$ が等しいとおいた式に, Fig.5の $D_{\mathrm{I}}$ の 值を代入す礼ば， $k_{\mathbf{I}} \sqrt{\varphi}$ 核容易に算出できる。この值を式 (13)k代入し，左辺と右辺が一致するときの $k_{\mathbf{r}}$ を求め,上 で算出した $k_{\mathbf{I}} \sqrt{ } \bar{\varphi}$ 比較すれば $\varphi$ が得られる。窒化温度 が $450,500,550,600^{\circ} \mathrm{C}$ のときの $\varphi$ の值はそれぞれ(3.73， $5.24,5.47,7.05) \times 10^{-4}$ であり，化合物層中のNの拡散 係数 $D_{\mathbf{I}}$ は拡散層中のそれ $\left(D_{\mathrm{I}}\right)$ に比してかなり低い值を示 すことがわかった，Fig.10は化合物層中のNの搪散係数 


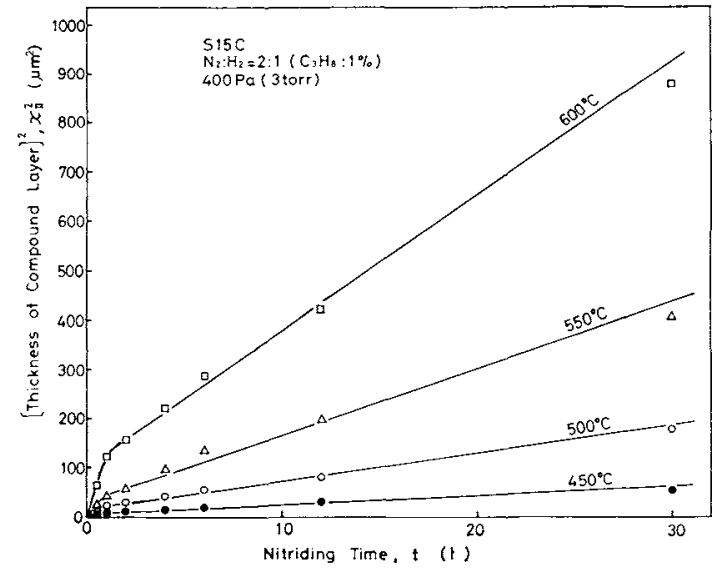

Fig.9 Relation between the square of the thickness of the compound layer and nitriding time.

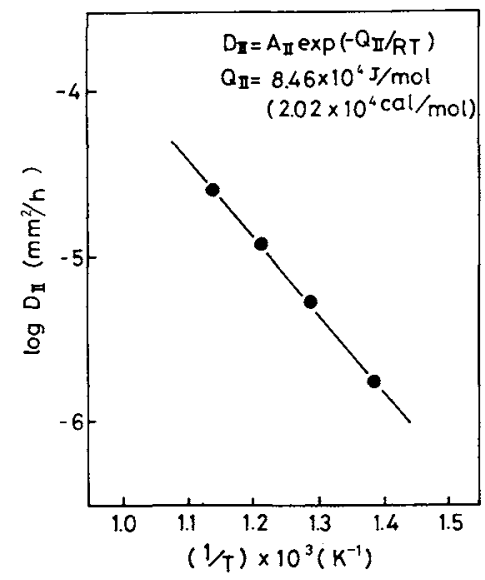

Fig.10 Relation between the diffusion coefficient of nitrogen in the compound layer and the reciprocal of absolute temperature.

$D_{\mathbf{I}}$ と窒化温度を Arrhenius の式で整理した図である.戝 から化合物層中のNの抬散の活性化エネルギーは $8.46 \times$ $10^{4} \mathrm{~J} / \mathrm{mol}\left(2.02 \times 10^{4} \mathrm{cal} / \mathrm{mol}\right)$ であることがわかった。

\section{IV. 結产}

S 15 C の試料をガス比, 全ガス圧, グロー電流密度, 冷 却方法をそれぞれ $\mathrm{N}_{2}: \mathrm{H}_{2}=2: 1$ (涯加 $\mathrm{C}_{3} \mathrm{H}_{8}: 1 \%$ )，400 Pa (3 tor r), $11.5 \mathrm{~A} / \mathrm{m}^{2}$, 水冷と同一にし, 窒化温度, 窒化時 閏を变化させて $\left(450 \sim 600^{\circ} \mathrm{C}, 0.25 \sim 30 \mathrm{~h}\right)$ イオン軟窒化し た後，拡散層および化合物層の生成速度について検討した 結果，次の結論を得た。

（1）抬散層の生成速度は放物線則に從亏。桩散層の化合
物層との界面空素濃度の温度依存性を考虑して得られた桩 散層中のNの抬散の活性化エネルギーは $7.53 \times 10^{4} \mathrm{~J} / \mathrm{mol}$ $\left(1.80 \times 10^{4} \mathrm{cal} / \mathrm{mol}\right)$ であり， $\alpha-\mathrm{Fe}$ 中のNのそれとよく一 致した。

(2) S 15C 試料へのグロー放電によるスパッタリング で, S15C 試料の近傍に同時にセットした純 Ti 試料から $\zeta-\mathrm{Fe}_{2} \mathrm{~N}$ のピークがX線回折により闹定された。このこと から, S $15 \mathrm{C}$ 試料の最表面窒素濃度は $6-\mathrm{Fe}_{2} \mathrm{~N}$ に相当する 11.35 wt\%と考党られた。ただし，S15C試料表面では 空化鉄は $\varepsilon-\mathrm{Fe}_{2-3} \mathrm{~N}$ および $\gamma^{\prime}-\mathrm{Fe}_{4} \mathrm{~N}$ しか同定されなかっ

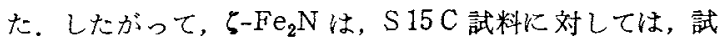
料表面に付着後，ただにNを試料内部に昖散しつつ，低 濃度の空化鉄である $\varepsilon-\mathrm{Fe}_{2-3} \mathrm{~N} や \gamma^{\prime}-\mathrm{Fe}_{4} \mathrm{~N}$ になると考兄ら れた。

（3）化合物層の生成速度は，窒化時間が $0.5 \mathrm{~h}$ 以下では 1 次則が成立し，表面反応支配である。しかし，0.5 h 以 上になるとほぼ放物線則が成立する。化合物愿の最表面窒 素濃度を $\zeta-\mathrm{Fe}_{2} \mathrm{~N}$ に相当する $11.35 \mathrm{wt} \%$ とし，化合物層 の拡散層との界面窒素濃度および应散層の化合物層との界 面窒素濃度の温度依存性，さらに抬散層中のNの拉散係数 を考慮して得られた化合物層中のNの昖散の活性化エネル ギーは $8.46 \times 10^{4} \mathrm{~J} / \mathrm{mol}\left(2.02 \times 10^{4} \mathrm{cal} / \mathrm{mol}\right)$ を示した。

（4）化合物層中のNの搪散係数は，桩散層中のそ礼に比

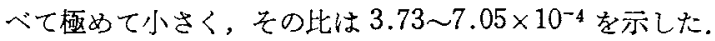

終りに，本研究に対し御指導と御㛹撻を賜放った京都大 学工学部 田村今男教授に厚く感謝いたします。

\section{文南}

（1）枝村瑞郎，牧村 実，梶川敦志，今井孝一，古都 政，国瀬 悟：日本金属学会誌，42(1978)，936。

（2）枝村瑞郎，牧村 奏，暒川敦志，今井孝一，古都 敏, 国瀬 悟: 日本金属学会誌, 42(1978), 942 .

(3) M. Hansen : Constitution of Binary Alloys, McGraw-Hill, (1958), 673.

（4）笛木和雄：日本金属学会会報，14(1975)，125.

（5）日本学術振興会製鋼第 19 委員会編：鉄鋼々合全元 素(上)，誠文堂新光社，(1966)，593。

（6）たとえば山中久彦：イオン窒化法,日干五業新聞社， (1976), 126.

（7）今井勇之進：日本金属学会会報，11(1972)，503.

(8) C.Wagner : quoted by W.Jost, Diffusion in Solids, Liquids and Gases, Academic Press, New York, (1952), 69.

(9) 玉川 元編：放電，実験物理学講座 19, 共立出版, (1975) , 26 .

（10）たとえば大和久重雄編：無公害熱好理技術，工業調 查会，(1973)，19。 